\title{
Morphological Responses of a Light-Demanding Alstonia scholaris and a Shade-Tolerant Eusideroxylon zwageri to the Air Humidity and Light Intensity
}

\author{
Bambang Irawan*, Rike Puspitasari Tamin, Rizky Ayu Hardiyanti
}

Forestry Department, Agriculture Faculty, University of Jambi, Campus Pinang Masak, Jambi-Muara Bulian Main Road, KM 15 Mendalo Darat, Jambi, Indonesia 36361

Received February 22, 2021/Accepted December 8, 2021

\begin{abstract}
The response of tropical trees to the change of light intensity has been reported to be varied among different species. Some reports argued that the growth was increasing parallel to the increasing of light intensity, but other reports mentioned that the sensitivity to the light intensity was depending on the species. Another environmental factor that has been scientifically proven to affect tree growth is humidity. While humidity itself also directly affected by the light intensity in the forest ecosystems. Therefore, it is possible that the growth pattern of trees under different light intensities is also affected by air humidity under the canopy. This research aimed to study the growth response of a light-demanding Alstonia scholaris and a shade-tolerant Eusideroxylon zwageri to the different levels of air humidity and light intensity. The experiment was conducted in Jambi, Indonesia from April to November 2019. The experiment was carried out using split plot design with factorial treatments. The main plot was the air humidity with three levels and the sub plots was light intensity with five levels. Four replicates were applied. In general, the A. scholaris tends to be more sensitive to the humidity and light intensity compared to E. zwageri. In particular, A. scholaris tends to be more sensitive to the light intensity while, E, zwageri is more sensitive to the humidity. However, there is also strong indication that the effects of light intensity to the growth, especially for A. scholaris, was affected by the humidity level.
\end{abstract}

Keyword: environmental factors, growth pattern, intolerant tree species, tolerant tree species, tropical tree species

*Correspondence author, email: irawanbam@yahoo.com

\section{Introduction}

The tree growth is not only influenced by genetic factors but also by the environmental factors. Many studies have been conducted in recent years to study the causal relationships between trees and local environmental factors in tropical forests (Rao \& Rajput, 1999; Ogata et al., 2001; Schongart et al., (2002); Yanez-Espinosa et al., 2006). Furthermore, Yanez-Espinosa et al. (2006) reported that each tropical species adapts to the different environmental conditions especially to the microclimatic factors. The mechanisms of the adaptation of each species to varying microclimatic factors determine the position of the species to the particular vertical strata and coexist in the subtropical and tropical rainforest.

Among environmental factors, light intensity and humidity are two primary environmental factors that determine the physiological processes of trees. Whitmore (1996) classified the tree species of rain forest into two main functional groups according to their growth and light requirements. Shade-tolerant species are able to germinate, survive, and grow in low light conditions. While lightdemanding species require a high-light environment for their growth and establishment. Similar classification was also proposed that forest tree species have been divided into two: (1) pioneers, which regenerate only in open conditions, and (2) non-pioneers, which can germinate and establish under the shade of forest canopy (Swaine \& Whitmore, 1988).
Experiment conducted by Veenendaal et al. (1996) supporting this classification. Pioneers showed markedly different responses in growth and biomass allocation to variation in irradiance, compared with non-pioneer shadebearers. Pioneers were able to increase RGR up to full irradiance. Thus, pioneers continue to increase RGR from light-limited to light-saturated RGR over a wider range of irradiance and show a lower convexity of the response curve than shade- bearers. The highest relative growth of pioneer species was obtained by the irradiance level below $8 \%$ of their ambient. The shade-bearer species (non-pioneer species) showed intermediate responses to light intensity differences.

However, different results reported by Osunkoya et al. (1994) who conducted research on 12 rainforest tree species. The species were chosen representing a wide array of taxa, ecological and morphological characteristics. They found that all species showed reduced growth with decreasing light intensity. Similar results also suggested by Denslow (1980) who found that light is one of the most limiting factors affecting the survival and plant growth in tropical rain forest. It is suggested that the rain-forest tree species are separated along the light gradient that determine niche differentiation among the plant species. Species of tropical rainforest should be specialized and adapted to the certain ranges of the gradient of light intensity, at which they may perform better than others. Implicitly, it is also assumed that in the low light, 
the growth performance of shade-tolerant species is hypothesized to be outgrown of pioneer species, whereas in high light intensity, the reverse is true. However, such changes in the growth performance ranks were not observed. For example, whether grow will be fast in the shade, as well as in high light intensity (Poorter, 1999). The same results were also reported that both species, large and small gap species, responded positively to increases in irradiance (Fetcher et al., 1983; Rincon \& Huante, 1993). However, the highest light dependency was obtained by the pioneer species (Rincon \& Huante, 1993).

Naturally, the light intensity and air temperature under forest ecosystem relate with the humidity levels. Research conducted by Georgi and Zafiriadis (2006) indicated that the air temperature decreases under the tree canopy while the air relative humidity increases. The tree canopy plays as one of major components that contribute towards microclimatic environments such as irradiation and wind velocity (Steven et al., 1986). The dense tree canopy can block over $95 \%$ of visible light from reaching the Earth's surface. While the amount of solar radiation absorbed by a tree canopy depends on its leaf area index (LAI) (Bonan, 2008). Parallel to this finding, the air humidity under the forest canopy usually has a higher relative humidity than air above forest canopy and in nearby open areas (Chen et al., 1993; Williams-Linera et al., 1998).

Hardwick et al. (2015) explained strong relationships between vegetation structures and microclimate. The plant canopies reduce the amount of energy that penetrate belowcanopy air by absorbing, scattering, and reflecting the incoming solar radiation. A denser canopy should result in cooler air temperature beneath the canopy soil. The cooler environment will have a higher relative humidity than the hotter environment. Moreover, the transpiration by the plants within the forest will also help to keep the air humidity level.

Many publications reported that air humidity plays an important role on the growth of tree species (Niglas et al., 2014; Rosenvald et al., 2014). As reported by Park \& Furukawa (1999) that the tropical tree species is more sensitive to the humidity compared to temperate ones. However, Lendzion and Leuzchner (2008) reported that the reduction of relative air humidity will also decrease the productivity and biomass of European beech (Fagus sylvatica) saplings. The biomass reduction was mainly due to a dramatically reduced leaf growth of beech under the elevated vapour pressure deficit (VPD) treatments. In fact, the global vapor pressure deficit has increased over recent decades and is expected to continue to rise in the future (Grossiord et al., 2020).

However, the understanding of tree growth responses to the change of humidity and light intensity especially on the tropical tree species is not well developed yet. The dichotomy between light demanding species and shade tolerant species still used as the main consideration for understanding this growth pattern. Even it is well understood that all tree species requires light for photosynthesis, and that the photosynthetic rate is increasing parallel to the increasing of light intensity. This research was conducted to study the growth response of a light-demanding Alstonia scholaris and a shade-tolerant Eusideroxylon zwageri to the different levels of air humidity and light intensity. This finding may contribute and enrich the understanding on this growth pattern theory. In fact, this knowledge is also urgent especially for determining the silvicultural techniques and species selection on restoration and rehabilitation of degraded forest as well as for natural forest management and cultivations.

\section{Methods}

The experiment was conducted over eight months from April 2019 to November 2019 at experimental station belongs to Forestry Department, University of Jambi. The experimental station is situated in $\mathrm{S} 1^{\circ} 37^{\prime} 11.49^{\prime \prime}$ and E103 $30^{\prime} 55.56^{\prime \prime}$. The altitude of the research location is \pm 35 $\mathrm{m}$ above sea level. The average monthly temperature is between $26.7^{\circ} \mathrm{C}$ and $28.0^{\circ} \mathrm{C}$ with the average monthly air humidity is from $80 \%$ to $87 \%$. The species studied included a light-demanding pioneer (A. scholaris) and a shade-tolerant old-forest species (Eusideroxylon zwageri Teisjm. \& Binn.). E. zwageri belongs to Lauraceae is well-known as shade bearer tree species. E. zwageri is able to grow under the humid climate and under climate with short dry season (Koopman \& Verhoef, 1938; Soedibja, 1952; Sidiyasa et al., 2009; Irawan, 2018). Soedibja (1952) reported that $E$. zwageri is a shade bearer species during immature stage. It is especially found in sandy soil and grows well under a fairly drained soil. Additionaly, Soerianegera (1974) reported that $E$. zwageri could grow in the habitat with dry sub-humid climate to humid climate with precipitation of 2,000 to 6,000 $\mathrm{mm}$ year $^{-1}$. While A. scholaris (L.) R. Br. belongs to Apocynaceae. A. scholaris is a medium-sized to large tree, that be able to grow up to $35 \mathrm{~m}$ in height (Ashton, 1988). The A. scholaris natural regeneration occurs preferentially in open areas at forest edges and in secondary forest. $A$. scholaris considered to be a light-demanding species (Ashton, 1988; Laumonier, 1996).

The experiment was carried out using split plot design with factorial treatments. The main plot was the air humidity with three levels namely humidity $50 \%(\mathrm{~h} 50)$, humidity $70 \%$ (h70), and humidity 75\% (h75) and the subplots was light intensity with five levels namely light intensity $100 \%\left(\mathrm{k}_{100}\right)$, light intensity 75\% (k75), light intensity 50\% $\left(\mathrm{k}_{50}\right)$, light intensity $25 \%\left(\mathrm{k}_{25}\right)$, and light intensity $0 \%\left(\mathrm{k}_{0}\right)$. The intensity levels are created using three levels of shade net $(25 \%, 50 \%$, and $75 \%$ ). The $100 \%$ of light intensity was created using clear and transparent UV plastics while for $0 \%$ of light intensity was created using $100 \%$ black cloth. All seedlings were covered under clear and transparent UV plastics to avoid direct water drops from the rain. The humidity levels are created by blowing water vapour with different intensity to the seedling blocks. Four replicates were applied for the experiment therefore, total number of experimental plots was 60 plots. Six seedlings were used for each plot that consisted of three E. zawgeri seedlings and three A. scholaris seedlings. The total number of seedlings was 360 . The average height of E. zawgeri seedlings was $65 \mathrm{~cm}$ with age of six months after germination, while the height of $A$. scholaris seedlings was $25 \mathrm{~cm}$ with the age of four months after germination. All seedlings were germinated and raised in the Nursery Center belongs to Forestry Department, University of Jambi. The seedlings were raised in the polybags. All seedlings were used as samples and one seedling for each 
treatment selected randomly as destructive sample for measuring the shoot and root dry weight.

The media that used for the seedlings was topsoil, sand, and organic matter with the ratio of 1:1:1 (Irawan, 2005). The different levels of air humidity in the main plot were established using mist spraying fans that located inside the plot for each replicate. The measurement of air humidity level had been conducted regularly using LogTrans 6 - GPRS produced by UIT Umweltleistungen, Germany. The surrounding area of plots and upper part of the plots were closed by transparent plastic to maintain the air humidity level. While different levels of shade net to the light penetration had been deployed to create different levels of light intensity.

Parameters and statistical analysis These parameters included: seedling height $(\mathrm{cm})$, diameter $(\mathrm{mm})$, leaf number, leaf area $\left(\mathrm{cm}^{2}\right)$, shoot dry weight $(\mathrm{g})$ and root dry weight $(\mathrm{g})$. The measuring method of seedling height was using the tape that measured from the root collar to the shoot tips. While the diameter measurement was conducted by caliper at $5 \mathrm{~cm}$ above root collar. The leaf area was measured using the Irvan View Software while for the dry weight was measured using analytic balance after the samples were dried using oven till reaching their dry weight. The data were subjected to statistical analysis: a one-way analysis of variance (ANOVA) with humidity and light intensity as treatment factors. The statistical test for all components of variance was determined at 0.05 significance level of Duncan multiple range test (DMRT) (Gomez \& Gomez, 1984).

\section{Results and Discussion}

Shade-tolerant old-forest species The F-values of six different parameters of $E$. zwageri and $A$, scholaris seedlings that treated by different levels of air humidity and light intensity at eight months after treatment was presented on Table 1. Table 1 shows that the effect of humidity is much pronounce to the E. zwageri compared to light intensity. Among six parameters, four parameters are highly significant different namely seedling height, diameter, leaf number and root dry weight while other two parameters are not significantly different. The light intensity only affected significantly on three parameters namely seedling height, diameter, and leaf number. While the interaction between humidity and light intensity is not significantly different for all parameters.

Table 2 shows that the humidity level of $75 \%$ provided

Table 1 The $F$-values of six different parameters of E. zwageri and A. scholaris seedlings that treated by different levels of air humidity and light intensity at eight months after treatments

\begin{tabular}{|c|c|c|c|c|}
\hline \multirow[t]{2}{*}{ Parameters } & \multicolumn{2}{|c|}{ E. zwageri } & \multicolumn{2}{|c|}{ A. scholaris } \\
\hline & Source of variances & $F$-values & Source of variances & $F$-values \\
\hline \multirow[t]{5}{*}{ Height } & Humidity & $4.63 * *$ & Humidity & 2.43 \\
\hline & Light intensity & $3.21 *$ & Light Intensity & $19.12 * *$ \\
\hline & Interaction between & 1.18 & Interaction between & $3.01 * *$ \\
\hline & light intensity and & & Light Intensity and & \\
\hline & humidity & & Humidity & \\
\hline \multirow[t]{5}{*}{ Diameter } & Humidity & $6.97 * *$ & Humidity & $4.15^{*}$ \\
\hline & Light intensity & $2.68 *$ & Light Intensity & $54.02 * *$ \\
\hline & Interaction between & 1.19 & Interaction between & $5.33 * *$ \\
\hline & light intensity and & & Light Intensity and & \\
\hline & humidity & & Humidity & \\
\hline \multirow[t]{5}{*}{ Leaf number } & Humidity & $9.69 * *$ & Humidity & 0.16 \\
\hline & Light intensity & $2.84 *$ & Light Intensity & $11.39 * *$ \\
\hline & Interaction between & 2.03 & Interaction between & 1.99 \\
\hline & light intensity and & & Light Intensity and & \\
\hline & humidity & & Humidity & \\
\hline \multirow[t]{5}{*}{ Leaf area } & Humidity & 2.25 & Humidity & $7.76^{* *}$ \\
\hline & Light intensity & 0.77 & Light Intensity & $5.27 * *$ \\
\hline & Interaction between & 0.95 & Interaction between & $3.00 *$ \\
\hline & light intensity and & & Light Intensity and & \\
\hline & humidity & & Humidity & \\
\hline \multirow[t]{5}{*}{ Root dry weight } & Humidity & $3.25^{*}$ & Humidity & 1.29 \\
\hline & Light intensity & 1.59 & Light Intensity & $39.45^{* *}$ \\
\hline & Interaction between & 0.64 & Interaction between & 0.81 \\
\hline & light intensity and & & Light Intensity and & \\
\hline & humidity & & Humidity & \\
\hline \multirow[t]{5}{*}{ Shoot dry weight } & Humidity & 1.60 & Humidity & 2.40 \\
\hline & Light intensity & 1.89 & Light Intensity & $29.37 * *$ \\
\hline & Interaction between & 0.80 & Interaction between & 0.99 \\
\hline & light intensity and & & Light Intensity and & \\
\hline & humidity & & Humidity & \\
\hline
\end{tabular}

Note: $*=$ significantly influenced on the $5 \%$ of variance analysis; $* *=$ highly significantly influenced based on the $1 \%$ of variance analysis 
significant differences to other levels of humidity for all parameters except leaf area and shoot and root dry weight. The treatments of $50 \%$ and $70 \%$ of humidity did not providing significant different effect to the growth of $E$. zwageri. The results confirmed the results of some other researches that humidity plays an important role about the growth rate of trees (Kaufmann, 1976; Park \& Furukawa, 1999; Lendzion \& Leuschner, 2008; Niglas et al., 2014; Rosenvald et al., 2014; Grossiord et al., 2020). The humidity mostly influences the stomatal sensitivities of the leaves (Kaufmann, 1976; Aasamaa \& Sõber, 2011) and helps maintaining cell turgidity, and hence helps in leaf expansion (Nataraja et al., 1998).

The optimum humidity level for the E. zwageri was around $50 \%$ to $70 \%$ and the growth rate is decreasing when reaching the humidity of $75 \%$ (Table 2 ). The ecological niche with high air humidity that needed by E. zwageri is confirming some reports (Koopman \& Verhoef, 1938; Soerianegara, 1974). However, the range of optimum humidity is little bit different to the reports that provided by Sidiyasa (2011) and Arifin et al. (2014). Sidiyasa (2011) reported that the average humidity around E. zwageri was $69.2 \%$ to $95.3 \%$ while Arifin et al. (2014) reported that humidity of E. zwageri habitat ranged between $66.43 \%$ to $83.76 \%$. The reports of both researchers were based on field measurement of microclimate around E. zwageri stand.

However, Lestari (2016) reported that when the humidity is decreasing under $50 \%$ (in her case $46.64 \%$ ), the growth rate of E. zwageri is lower compared to E. zwageri seedlings that planted under humidity level of $53.86 \%$. Lendzion and Leuschner (2008) also confirmed that the productivity of the trees that planted in the climate chambers reduced to $68 \%$ when the air humidity was reduced by $40 \%$. Lendzion and Leuschner (2008) also confirmed that the plant biomass declined by $30 \%$ when relative air humidity was $15 \%$ lower for the experiment that conducted on the forest floor. Grossiord et al. (2020) explained that VPD conditions that appear under low air humidity reduce stomatal conductance and increasing plant water losses through transpiration associate with simultaneously reduce photosynthesis rate. These impacts vary across biomes and among plant functional types. However, they will influence in reducing primary productivity and amplifying drought-induced plant mortality worldwide. The same results were also performed by Yuan et al. (2019), showing that the decreasing of terrestrial gross primary production is due to increasing of VPD. Further explanation also reported by Niglas et al. (2014), saying that the low level of soil water availability during the dry years mitigated by the higher air humidity on broadleaved trees. The trees reduce the stomatal limitation to photosynthesis that allowing higher net photosynthetic rates and supporting higher growth rates.

The effect of light intensity to the growth of E. zwageri also presented on Table 2. Table 2 shows that all growth parameters of E. zwageri was significantly different among treatments except for leaf area. Among the treatments, light intensity of $50 \%$ and $75 \%$ performed better in influencing the growth of E. zwageri. The growth rate of E. zwageri mostly decreasing by increasing light intensity above $75 \%$ and below $50 \%$. The response of E. zwageri to light intensity based on the results of this experiment mostly confirmed other research results (Swaine \& Whitmore, 1988; Whitmore, 1996; Veenendaal et al., 1996; Eschenbach et al., 1998). However, the growth pattern of E. zwageri to the increasing light intensity does not confirm the research results that the growth of the trees will be increased parallel to the increasing of light intensity (Denslow, 1980; Fetcher et al., 1983; Rincon \& Huante, 1993; Osunkoya et al., 1994; Poorter, 1999). Table 2 shows that the optimum light intensity to the growth of $E$. zwageri is around $50 \%$ to $75 \%$ which approximately similar to the findings of a study by Lestari (2016).

The interaction between humidity and light intensity was not significantly different to the growth of $E$. zwageri. It means that the effects of humidity on the growth of $E$. zwager $i$ were not related or influenced by the changes of light intensity. Based on this result, the possibility of shade tolerant species E. zwageri to grow well under full sunlight as long as the level of air humidity is kept high, is not confirmed. Although all trees require light for photosynthesis, but since shade tolerant species has been adapted to the ecological condition with low light intensity, the increasing growth of those species does not necessarily correlate with increasing light intensity. The slow growth response that revealed by $E$. zwageri due to increasing of light intensity also confirmed research result that reported by Fetcher et al. (1983) The small gap tree species (shade tolerant species) tend to be less plastic compares to light demanding species under increased light intensities.

Tabel 2 Mean values of six traits of Eusideroxylon zwageri Teijsm. \& Binn. seedlings that treated by different levels of air humidity and light intensity at eight months after treatments

\begin{tabular}{lrrrrrr}
\hline Treatments & $\begin{array}{c}\text { Height } \\
(\mathrm{cm})\end{array}$ & $\begin{array}{c}\text { Diameter } \\
(\mathrm{mm})\end{array}$ & $\begin{array}{c}\text { Leaf } \\
\text { number }\end{array}$ & $\begin{array}{c}\text { Leaf area } \\
\left(\mathrm{cm}^{2}\right)\end{array}$ & $\begin{array}{c}\text { Root dry } \\
\text { weight }(\mathrm{g})\end{array}$ & $\begin{array}{c}\text { Shoot dry } \\
\text { weight }(\mathrm{g})\end{array}$ \\
\hline Humidity $50 \%$ & $81.76 \mathrm{a}$ & $7.587 \mathrm{a}$ & $10.68 \mathrm{a}$ & $12.80 \mathrm{a}$ & $6.63 \mathrm{ab}$ & $2.89 \mathrm{a}$ \\
Humidity 70\% & $80.04 \mathrm{a}$ & $8.760 \mathrm{a}$ & $14.05 \mathrm{a}$ & $18.16 \mathrm{a}$ & $8.02 \mathrm{a}$ & $5.27 \mathrm{a}$ \\
Humidity 75\% & $49.09 \mathrm{~b}$ & $4.518 \mathrm{~b}$ & $4.60 \mathrm{~b}$ & $8.60 \mathrm{a}$ & $2.31 \mathrm{~b}$ & $3.09 \mathrm{a}$ \\
\hline Light intensity $100 \%$ & $57.34 \mathrm{~b}$ & $6.16 \mathrm{ab}$ & $10.28 \mathrm{ab}$ & $14.52 \mathrm{a}$ & $5.83 \mathrm{ab}$ & $2.24 \mathrm{~b}$ \\
Light intensity 75\% & $76.43 \mathrm{ab}$ & $7.48 \mathrm{ab}$ & $13.51 \mathrm{a}$ & $15.62 \mathrm{a}$ & $8.68 \mathrm{a}$ & $6.71 \mathrm{a}$ \\
Light intensity 50\% & $100.97 \mathrm{a}$ & $9.11 \mathrm{a}$ & $11.81 \mathrm{a}$ & $10.95 \mathrm{a}$ & $4.43 \mathrm{ab}$ & $4.18 \mathrm{ab}$ \\
Light intensity 25\% & $66.45 \mathrm{~b}$ & $7.60 \mathrm{ab}$ & $8.50 \mathrm{ab}$ & $16.80 \mathrm{a}$ & $7.51 \mathrm{ab}$ & $3.42 \mathrm{ab}$ \\
Light intensity 0\% & $50.30 \mathrm{~b}$ & $4.43 \mathrm{~b}$ & $4.79 \mathrm{~b}$ & $8.05 \mathrm{a}$ & $1.81 \mathrm{~b}$ & $2.19 \mathrm{~b}$ \\
\hline
\end{tabular}

Note: The mean values that are followed by the same letters are not significantly different based on $5 \%$ of Duncan multiple range test. 
Light-demanding pioneer species. On the other hand, the effects of light intensity are much pronounce to the growth of A. scholaris compared to air humidity. Table 1 shows that all six parameters are significantly influenced by light intensity while only two parameters are significantly affected by air humidity levels namely seedling diameter and leaf area. The interaction between humidity and light intensity is also significantly different for three parameters namely seedling height, diameter, and leaf area.

All growth parameters performed the same trend whereas the growth rate of $A$. scholaris is increasing parallel to the increasing of light intensity. The sensitivity of $A$. scholaris to the light intensity that revealed by this experiment confirmed some other research findings (Denslow, 1980; Fetcher et al., 1983; Rincon \& Huante, 1993; Osunkoya et al., 1994; Poorter, 1999). Vincent (2006) reported that A. scholaris revealed more pronounce on the growth dynamics compared to Durio zibethinus, Hevea brasiliensis, and Lansium domesticum. A. scholaris, leaves produced by faster elongating main shoot. The main shoot leaves had life spans that were significantly shorter than those of leaves produced by the branches. Among the four studied species, the $A$. scholaris seedlings provided the maximum level of plasticity in leaf life span compared to other species. Additionally, the mean leaf emergence rate (LER) of $A$. scholaris appeared to reach a maximum level under full sunlight and to decrease parallel to the increase of shade intensity (Vincent, 2006), therefore, A. scholaris is considered as a light-demanding species (Ashton, 1988). However, there is a tendency that the light intensity is not an independent factor in influencing the growth rate of $A$. scholaris. The effects of light intensity tend to be depended on the humidity level. When the humidity is high (more that $70 \%$ in this case), the diameter growth rate is kept increasing until $100 \%$ of light intensity. While in the environment condition with low level of humidity, the trend of height and leaf number growth was decreasing at about $75 \%$ of light intensity or even below $50 \%$ of light intensity (Table 3)

The result of this experiment can be used to explain the behavior of some tree species that do not perform linearly to the increasing light intensity. Air humidity may play role as the limiting factor for the tree growth. It is the reason why some researchers reported differently on the responses of tree species to the light intensity.
The comparison between light-demanding pioneer and a shade-tolerant old-forest species. The response to the air humidity and light intensity between $E$. zwageri and $A$. scholaris tend to be different. In general, the $A$. scholaris tend more sensitive to the light intensity and interactive effect of humidity and light, compared to E. zwageri. It is indicated that the influence intensity of the humidity and light as well as interaction between both parameters on growth of both species were more pronounce on $A$. scholaris than E. zwageri. In particular, $A$. scholaris tend to be more sensitive to the light intensity, while $E$, zwageri is more sensitive to the humidity as shown in Table 1, Table 2, and Table 3.

The sensitivity of $E$. zwageri to the humidity is possibly related with the strategy of this species to the ecological habitat where E. zwageri mostly grows and adapts to the low light intensity. This tree species is adapted to grow under the shade environmental conditions (Soedibja, 1952). As explained by Aasamaa, and Sõber (2011) that the highly sensitive and strictly regulated responses of their stomata are the responsible adaptation capability of the slow grower species in their ecological niches. The adaptation of $E$. zwageri to the air humidity also reported by Sidiyasa et al. (2009) that air humidity may also have a significant effect on the presence and growth of the E. zwageri. E. zwageri will only grow well in locations where the surrounding vegetation is dense and in good condition. Due to the dense vegetation cover, the humidity level under the forest stands will be constant and relatively high. Conversely, in places where the vegetation has been severely damaged, the $E$. zwageri trees are no longer found.

Related to the light intensity, the growth pattern of $E$. zwageri and $A$. scholaris was also different. The $A$. scholaris mostly responded linearly to the increasing light intensity while E. zwageri was not. The different growth performance between pioneer tree species and gap tree species was reported also by Fetcher et al. (1983). They reported that growth of Heliocarpus, a pioneer or large gap species is more plastic than that of Diptery that is a small gap species in response to changes in irradiance. However, both species responded positively to increases in irradiance to specific extents. The results of this experiment also confirmed publication by Veenendaal et al. (1996).

Tabel 3 Mean values of six traits of Alstonia scholaris seedlings that treated by different levels of air humidity and light intensity at eight months after treatments

\begin{tabular}{lrrrrrr}
\hline \multicolumn{1}{c}{ Treatments } & $\begin{array}{c}\text { Height } \\
(\mathrm{cm})\end{array}$ & $\begin{array}{c}\text { Diameter } \\
(\mathrm{mm})\end{array}$ & $\begin{array}{c}\text { Leaf } \\
\text { number }\end{array}$ & $\begin{array}{c}\text { Leaf area } \\
\text { Root dry } \\
\text { weight }\end{array}$ & $\begin{array}{c}\text { Plant dry } \\
\text { weight }\end{array}$ \\
\hline Humidity $50 \%$ & $63.964 \mathrm{~b}$ & $5.220 \mathrm{ab}$ & $27.242 \mathrm{a}$ & $3.378 \mathrm{a}$ & $2.499 \mathrm{a}$ & $6.949 \mathrm{a}$ \\
Humidity $70 \%$ & $72.583 \mathrm{a}$ & $5.648 \mathrm{a}$ & $26.202 \mathrm{a}$ & $2.629 \mathrm{~b}$ & $1.931 \mathrm{a}$ & $5.131 \mathrm{~b}$ \\
Humidity $75 \%$ & $66.458 \mathrm{ab}$ & $4.826 \mathrm{~b}$ & $26.850 \mathrm{a}$ & $2.501 \mathrm{~b}$ & $1.930 \mathrm{a}$ & $5.824 \mathrm{ab}$ \\
\hline Light intensity $100 \%$ & $74.776 \mathrm{~b}$ & $7.639 \mathrm{a}$ & $30.585 \mathrm{a}$ & $2.859 \mathrm{ab}$ & $5.435 \mathrm{a}$ & $10.880 \mathrm{a}$ \\
Light intensity 75\% & $86.751 \mathrm{a}$ & $6.858 \mathrm{~b}$ & $31.166 \mathrm{a}$ & $3.437 \mathrm{a}$ & $3.180 \mathrm{~b}$ & $9.958 \mathrm{a}$ \\
Light intensity $50 \%$ & $73.661 \mathrm{~b}$ & $4.603 \mathrm{c}$ & $30.168 \mathrm{a}$ & $3.194 \mathrm{a}$ & $0.915 \mathrm{c}$ & $4.154 \mathrm{~b}$ \\
Light intensity $25 \%$ & $57.417 \mathrm{c}$ & $3.567 \mathrm{~d}$ & $24.111 \mathrm{~b}$ & $2.490 \mathrm{~b}$ & $0.443 \mathrm{c}$ & $2.103 \mathrm{~b}$ \\
Light intensity 0\% & $45.787 \mathrm{~d}$ & $3.489 \mathrm{~d}$ & $17.793 \mathrm{c}$ & $2.199 \mathrm{~b}$ & $0.625 \mathrm{c}$ & $2.745 \mathrm{~b}$ \\
\hline
\end{tabular}

Note: The mean values that are followed by the same letters are not significantly different based on $5 \%$ of Duncan multiple range test. 


\section{Conclusion}

The conclusions of this study that the response to the air humidity and light intensity between E. zwageri and $A$. scholaris tend to be different. Generally, the $A$. scholaris tend to be more sensitive to the light intensity while E. zwageri is more sensitive to the humidity. There is a strong indication that the effects of light intensity to the growth was affected by the humidity level. When the humidity is high, the increasing light intensity increases the growth rate even when the light intensity reached to $100 \%$. While in the environment condition with low level of humidity, the trend of growth is decreasing about $75 \%$ or even below $50 \%$ of light intensity.

\section{Acknowledgment}

We would like to show gratitude to Yudhi Pangestu and Adi Karta for helping the field works; Dr. Delphine Clara Zemp and Eduard Januarlin Siahaan for preparing the instrument for measuring the light intensity and humidity. The study was funded by Non-Tax Revenue, Forestry Faculty, University of Jambi, 2019.

\section{References}

Arifin, Y. F., Itta, D., \& Raihana (2014). Study of ecological conditions and management systems of ironwood (Eusideroxylon zwageri Teijsm. \& Binn.) from natural forests in South Kalimantan as cultivation and conservation efforts. In I. Z. Siregar, B. Irawan, E. Ahmad, \& E. Fajriani (Eds.), Proceedings of the national seminar on the status and preservation of bulian (Eusideroxylon zwageri Teijsm. \& Binn.) in Jambi Province.

Aasamaa, K. \& Sõber, A. (2011). Stomatal sensitivities to changes in leaf water potential, air humidity, $\mathrm{CO}_{2}$ concentration and light intensity, and the effect of abscisic acid on the sensitivities in six temperate deciduous tree species. Environmental and Experimental Botany, 71, 72-78. https://doi.org/10.1016/j.envexpbot.2010.10.013

Ashton, P. S. (1988). Manual of the non-dipterocarp trees of Sarawak. Kuching: Forest Department Sarawak.

Bonan, G. B. (2008). Ecological climatology (2nd ed.). Cambridge: Cambridge University Press. https://doi.org/ 10.1017/CBO9780511805530

Chen, J., Franklin, J. F., \& Spies, T.A. (1993). Contrasting microclimates among clear cut,edge, and interior of oldgrowth Douglas-fir forest. Agricultural and Forest Meteorology, 63, 219-237. https://doi.org/10.1016/ 0168-1923(93)90061-L

Denslow, J.S. (1980). Gap partitioning among tropical rain forest trees. Biotropica, 12, 47-55. https://doi.org/ $10.2307 / 2388156$

Eschenbach, C., Glauner, R., Kleine M. \& Kappen, L. (1998). Photosynthesis rates of selected tree species in lowland dipterocarp rainforest of Sabah, Malaysia. Trees, 12, 356-365. https://doi.org/10.1007/s004680050162
Fetcher, N., Boyd, R. Strain, \& Oberbauer, S. F. (1983). Effects of light regime on the growth, leaf morphology, and water relations of seedlings of two species of tropical trees. Oecologia, 58, 314-319. https://doi.org/10.1007/ BF00385229

Georgi, N. J. \& Zafiriadis, K. (2006). The impact of park trees on microclimate in urban areas. Urban Ecosystems, 9, 195-209. https://doi.org/10.1007/s11252-006-8590-9

Gomez, K. A., \& Gomez, A. A. (1984). Statistical procedures for agricultural research. John Wiley and Sons, Inc.

Grossiord, C., Buckley, T. N., Cernusak. L. A., Novick, K. A., Poulter, B., Siegwolf, R. T. W., ..., \& McDowell, N. G. (2020). Plant responses to rising vapor pressure deficit. New Phytologist, 226(6), 1550-1566. https://doi.org/ $10.1111 / \mathrm{nph} .16485$

Hardwick, S. R., Toumi R., Pfeifer, M., Turner, E. C., Nilus, R., \& Ewers, R. M. (2015). The relationship between leaf area index and microclimate in tropical forest and oil palm plantation: Forest disturbance drives changes in microclimate. Agricultural and Forest Meteorology, 201, 187-195. https://doi.org/10.1016/j.agrformet.2014.11. 010

Irawan, B. (2005). Ironwood (Eusideroxylon zwageri Teijsm. \& Binn.) and its varieties in Jambi, Indonesia. Göttingen: Cuvillier Verlag.

Kaufmann, M. R. (1976). Stomatal response of Engelmann spruce to humidity, light, and water stress. Plant Physiol, 57, 898-901. https://doi.org/10.1104/pp.57.6.898

Koopman, M.J.F., \& Verhoef, L. (1938). Eusideroxylon zwageri, The ironwood of Borneo and Sumatera. Tectona, 31, 381-399.

Laumonier Y. (1996). The vegetation and physiography of Sumatra. Kluwer Academic Publishers. https://doi.org/ 10.1007/978-94-009-0031-8

Lendzion, J., \& Leuschner, C. (2008). Growth of european beech (Fagus sylvatica L.) saplings is limited by elevated atmospheric vapour pressure deficits. Forest Ecology and Management, 256, 648-655. https://doi.org/10.1016/ J.FORECO.2008.05.008

Poorter, L. (1999). Growth responses of 15 rain-forest tree species to a light gradient: The relative importance of morphological and physiological traits. Functional Ecology, 13, 396-410. https://doi.org/10.1046/j.13652435.1999.00332.x

Lestari, Y. (2016). The effects of light intensity and humidity to the germination and growth of ironwood seedlings (Eusideroxylon zwageri Teijsm. \& Binn.) in the polybags [thesis]. Jambi: University of Jambi.

Niglas, A., Kupper, P,. Tullus, A., \& Sellin, A. (2014). 
Responses of sap flow, leaf gas exchange and growth of hybrid aspen to elevated atmospheric humidity under field conditions. AoB PLANTS, 6, plu021. https://doi.org/10.1093/aobpla/plu021

Ogata, Y., Nobuchi, T., Fujita, M., \& Sahri, M. H. (2001). Growth rings and tree growth in young para rubber trees from Peninsular Malaysia. IAWA Journal, 22, 43-56. https://doi.org/10.1163/22941932-90000267

Osunkoya, O. O., Ash, J. E., Hopkins, M. S. \& Graham, A. W. (1994). Influence of seed size and seedling ecological attributes on shade-tolerance of rain-forest tree species in Northern Queensland. Journal of Ecology, 82, 149-163. https://doi.org/10.2307/2261394

Park, S. Y. \& Furukawa, A. (1999). Photosynthetic and stomatal response of two tropical and two temperate trees to atmospheric humidity. Photosynthetica, 36, 181. https://doi.org/10.1023/A:1007039308629

Rao, K. S., \& Rajput, K. S. (1999). Seasonal behavior of vascular cambium in teak (Tectona grandis) growing in moist deciduous and dry deciduous forests. IAWA Journal, 20, 85-93. https://doi.org/10.1163/2294193290001553

Rincon, E. \& Huante, P. (1993). Growth responses of tropical deciduous tree seedlings to contrasting light conditions. Trees, 7, 202-207.https://doi.org/10.1007/BF00202074

Rosenvald, K., Tullus, A., Ostonen, I., Uri, V., Kupper, K., Aosaar, J., \& Lõhmus, K. (2014). The effect of elevated air humidity on young silver birch and hybrid aspen biomass allocation and accumulation - Acclimation mechanisms and capacity. Forest Ecology and Management, 330, 252-260. https://doi.org/10.1016/ j.foreco.2014.07.016

Schongart, J., Piedade, M. T. F., Ludwigshausen, S., Horna, V., \& Worbes, M. (2002). Phenology and stem-growth periodicity of tree species in Amazonian floodplain forests. Journal of Tropical Ecology, 18, 581-597. https://doi.org/10.1017/S0266467402002389

Sidiyasa, K., Atmoko. T., Ma'ruf. A., \& Mukhlisi. (2009). Study on morphological diversity, ecology, mother tree and ironwood conservation in Kalimantan. Report on Research Results in Collaboration with the Ministry of National Education and Samboja Seed Technology Research Institute.

Sidiyasa, K. (2011). Distribution, potential and management of ulin in Indonesia. In M. Bismark, \& Murniati (Eds.), Proceedings of the national workshop on conservation status and conservation strategy formulation of endangered tree species (ulin, ebony and michelia).

Soedibja, R. S. (1952). Penjelidikan tentang tumbuh dan ekologi kaju besi (Eusideroxylon zwageri T. et B.) di lingkungan hutan Semandai (Palembang). Rimba Indonesia, 1(5), 215-223.

Soerianegara, I. (1974). Ecological researches relevant to current silviculture problems. Coordinated study of lowland forest of Indonesia. Bogor: BIOTROP and IPB

Steven, M. D., Biscoe, P. V., Jaggard, K. W. \& Paruntu. (1986). Foliage cover and radiation interception. Field Crops Research, 13, 75-87. https://doi.org/10.1016/ 0378-4290(86)90012-2

Swaine, M. D. \& Whitmore, T. C. (1988). On the definition of ecological species groups in tropical rain forests. Vegetatio, 75, 81-86. https://doi.org/10.1007/Bf000 44629

Veenendaal, E., Swaine, M. D. \& Owusu-Afriyie, K. (1996) Responses of west african forest tree seedlings to irradiance and soil fertility. Functional Ecology, 10 (4), 501511.https://doi.org/10.2307/2389943

Vincent G. (2006). Leaf life span plasticity in tropical seedlings grown under contrasting light regimes. Annals of Botany, 97, 245-255. https://doi.org/10.1093/ aob/mcj023

Whitmore, T. C. (1996). A review of some aspects of tropical rain forest seedling ecology with suggestions for further enquiry (pp. 3-39). In M. D. Swaine (Ed.), The ecology of tropical forest tree seedlings. MAB UNESCO Series, vol. 17. Paris: Parthenon.

Williams-Linera, G., Domínguez-Gastelú, \& García-Zurita, M. E., (1998). Micro environment and floristics of different edges in a fragmented tropical rainforest. Conservation Biology, 12(5), 1091-1102. https://doi.org/ 10.1046/J.1523-1739.1998.97262.X

Yanez-Espinosa, L., Terrazas, T., \& Lopez-Mata, L. (2006). Integrated analysis of tropical trees growth: A multivariate approach. Annals of Botany, 98, 637-645. https://doi.org/10.1093/aob/mcl142

Yuan, W., Zheng, Y., Piao, S., Ciais, P., Lombardozzi, D., Wang, Y. P., ..., \& Yang, S. (2019). Increased atmospheric vapor pressure deficit reduces global vegetation growth. Science Advances, 5(8). https://doi.org/10.1126/ sciadv.aax 1396 